\title{
Purification and Some Properties of Soluble Phospholipase B from Baker's Yeast (Saccharomyces cerevisiae)
}

\author{
Michiko ICHImasa and Masami Shiobara \\ Department of Biology, Faculty of Science, Ibaraki University, \\ Bunkyo, Mito, Ibaraki 310, Japan
}

Received September 6, 1984

\begin{abstract}
Phospholipase B from baker's yeast (Saccharomyces cerevisiae) was purified by acid treatment of the crude extract, ammonium sulfate fractionation, and column chromatographies on DEAESepharose CL-6B, Sepharose 4B, and Bio-Gel HTP. The purified preparation had lysophospholipase activity and phospholipase $\mathrm{B}$ activity in a ratio of $16: 1$. The optimum $\mathrm{pH}$ of both activities was $3.5 \sim 4.0$. The enzyme was a glycoprotein and its molecular size was somewhat heterogeneous, ranged from about 280,000 to 420,000 by gel filtration. Phospholipase B activity was strongly stimulated by $0.1 \%$ DOC, but lysophospholipase activity was completely inhibited by the detergent. Neither activity was stimulated by $\mathrm{Ca}^{2+}$ and both were inhibited by SDS, Triton X100 , and $\mathrm{Fe}^{3+}$. The enzyme hydrolyzed the acyl ester bonds of phosphatidylcholine sequentially, first the 2-acyl and then the 1-acyl groups. The $K m$ values for phosphatidylcholine and lysophosphatidylcholine were $0.63 \mathrm{~mm}$ and $0.05 \mathrm{~mm}$, respectively.
\end{abstract}

Aqueous extracts of intact yeast cells contained phospholipid-deacylating activities. ${ }^{1 \sim 3)}$ In our previous paper, ${ }^{4)}$ we reported the distribution of phospholipase B and its accompanying lysophospholipase activities in the membrane fraction and lysophospholipase activity in the soluble fraction obtained from cell homogenates of baker's yeast and the purification of the membrane-bound phospholipase B. In a preliminary experiment, it was found that lysophospholipase in the $100,000 \times g$ supernatant fraction obtained from a yeast cell homogenate had latent phospholipase B activity. In this paper, partial purification and some properties of this enzyme are described.

\section{MATERIALS AND METHODS}

Materials. $\quad$ L- $\alpha$-Phosphatidylcholine and $\quad \mathrm{L}-\alpha$-lysophosphatidylcholine (1-acyl-sn-glycero-3-phosphocholine) were obtained from the Green Cross Co. (Osaka). 1-Palmitoyl-2-[ $\left[{ }^{14} \mathrm{C}\right]$ oleoyl-sn-glycero-3-phosphocholine was purchased from Dhom Products and $1-\left[1-{ }^{14} \mathrm{C}\right] \mathrm{pal}-$ mitoyl-2-acyl-sn-glycero-3-phosphocholine was prepared biosynthetically by intraportal injection of $\left[1-{ }^{14} \mathrm{C}\right] \mathrm{pal}-$ mitate into rats as described by Åkesson et al. ${ }^{5)}$ 2-Acyl$s n$-glycero-3-phosphocholine was prepared from beef heart lecithin by the method of Eibl and Lands. ${ }^{6)}$ Pure reference proteins used for molecular weight determination were purchased from Pharmacia Fine Chemicals (Uppsala, Sweden). Bio-Lyte 3/5 and 3/10 were obtained from Bio-Rad Laboratories (Richmond, U.S.A.).

Preparation of the soluble fraction. Pressed baker's yeast ( $S$. cerevisiae) with no additives was obtained from Sankyo Co., Ltd (Tokyo). Fresh yeast cells were washed three times with cold $25 \mathrm{~mm}$ Tris- $\mathrm{HCl}$ buffer ( $\mathrm{pH} 7.5$ ), suspended in 5 volumes of the same cold buffer containing $0.5 \mathrm{~mm} p$ chloromercuribenzoate and disrupted by shaking with glass beads $(0.6 \mathrm{~mm}$ diameter, $20 \mathrm{~g}$ per $10 \mathrm{ml}$ of a $20 \%$ cell suspension) using a Homogenon model IIIA (Ohtake Works, Tokyo) for $20 \mathrm{~min}$ ( $5 \mathrm{~min}$ shaking followed by 15 min cooling, repeated four times) in an ice bath. After centrifugation at $1,000 \times g$ for $5 \mathrm{~min}$ to remove glass beads and cell debris, the supernatant was centrifuged at $130,000 \times g$ for $70 \mathrm{~min}$. The supernatant was used as the soluble fraction.

Enzyme assay. The standard incubation mixture for phospholipase B activity contained $1 \mathrm{~mm}$ phosphatidylcholine, $0.1 \%(2.4 \mathrm{~mm})$ sodium deoxycholate (DOC), $160 \mathrm{~mm}$ acetate buffer ( $\mathrm{pH} 3.5)$, and the enzyme preparation in $0.5 \mathrm{ml}$. An aqueous dispersion of the substrate was

Abbreviations: DOC, sodium deoxycholate; SDS, sodium dodecyl sulfate; PAS, periodic acid-Schiff reagent. 
prepared by ultrasonic treatment. Incubation was done for $10 \mathrm{~min}$ or more at $37^{\circ} \mathrm{C}$ with shaking. The reaction was stopped by addition of $0.3 \mathrm{ml}$ of $10 \%$ cold trichloroacetic acid and $0.1 \mathrm{ml}$ of $5 \%$ bovine serum albumin or by addition of chloroform-methanol ( $1: 1$, by volume). ${ }^{7)}$ After centrifugation, enzyme activity was assayed by measuring glycero-3-phosphocholine in the supernatant by the method of Bartlett. ${ }^{8)}$ When ${ }^{14} \mathrm{C}$-labeled phosphatidylcholine was used as the substrate, the reaction was stopped by addition of 2.5 volumes of cold methanol and the products were partitioned between chloroform and aqueous methanol by the procedure of Bligh and Dyer. ${ }^{9)}$ The chloroform phase was concentrated and spotted on precoated thin-layer plates of silica gel 60 (Merck Co.) with carrier lipids (lysophosphatidylcholine and palmitic acid) and developed with chloroform-methanol-water (65:25:1, by volume). The spots corresponding to phosphatidylcholine, lysophosphatidylcholine, and fatty acids were scraped off and put into scintillation vials and the radioactivity was measured with a liquid scintillation spectrometer. When phosphate buffer was contained in the reaction mixture, enzyme activity was assayed by measuring residual substrate in the chloroform phase that was obtained by the procedure of Bligh and Dyer. ${ }^{9)}$ The incubation mixture for lysophospholipase activity contained $0.25 \mathrm{~mm}$ lysophosphatidylcholine, $160 \mathrm{~mm}$ acetate buffer ( $\mathrm{pH} 3.5$ ), and the enzyme preparation in $0.5 \mathrm{ml}$. Incubation conditions and procedures were the same as above. One unit of phospholipase B and lysophospholipase activities was defined as the amount of enzyme which caused a decrease of $1 \mu \mathrm{mol}$ of substrate per min under these conditions.

Molecular weight determination by gel filtration. The enzyme preparation containing standard proteins in $1.6 \mathrm{ml}$ of $25 \mathrm{~mm}$ Tris- $\mathrm{HCl}$ buffer, $\mathrm{pH} 7.5$, was put on a Sepharose $4 \mathrm{~B}$ column $(2.5 \times 72 \mathrm{~cm})$ and eluted with the same buffer at a flow rate of $9 \mathrm{ml}$ per hr. Fractions of $4.0 \mathrm{ml}$ were collected and an aliquot was used for the lysophospholipase assay. Aldolase $(158,000)$, catalase $(232,000)$, ferritin $(440,000)$, and thyroglobulin $(669,000)$ were used as standard proteins. The molecular weight of the enzyme was calculated by the method of Andrews. ${ }^{10)}$

Disc gel electrophoresis. Agarose-polyacrylamide gel electrophoresis was done at $\mathrm{pH} 8.3$ in a $0.7 \%$ agarose- $-1.5 \%$ acrylamide gel $(c=5 \%)$ by the method of Nakamura et al. ${ }^{11)}$ Gels were stained with Amido Black $10 \mathrm{~B}$ for protein and periodic acid-Schiff reagent (PAS) for carbohydrate. ${ }^{12)}$ Disc gel electrophoresis with sodium dodecyl sulfate (SDS) was done by the method of Weber and Osborn $^{13)}$ on $4 \%$ polyacrylamide gel. Gels were stained with periodic acid-Schiff reagent (PAS) and double-stained with Coomassie Brilliant Blue G-250 by the procedure of Okumura et al. ${ }^{7)}$

Determination of isoelectric point. Isoelectric focusing was done at $4 . \mathrm{C}$ for $16 \mathrm{hr}$ with Bio-Lyte ampholytes $(1.25 \%$ total concentration of Bio-Lyte, consisting of $40 \%$ of Bio-Lyte $3 / 10$ and $60 \%$ of Bio-Lyte $3 / 5$ ) forming a $\mathrm{pH}$ gradient of 3 to 5 in a $10 \mathrm{ml}$ column under a sucrose gradient of $5 \sim 20 \%$ by the method of Behnke et al. ${ }^{14)}$

Protein determination. The protein content was measured by the method of Lowry et al. ${ }^{15)}$ with bovine serum albumin as a standard.

\section{RESULTS}

\section{Purification of phospholipase B}

1. Acid treatment. The $\mathrm{pH}$ of the soluble fraction obtained from $200 \mathrm{~g}$ of yeast cells was adjusted to 4.0 with one-fourth volume of $0.75 \mathrm{M}$ sodium acetate buffer $(\mathrm{pH} 4.0)$. The solution was left in an ice-bath for $30 \mathrm{~min}$ and the precipitate was then removed by centrifugation at $10,000 \times g$ for $15 \mathrm{~min}$. Seventyeight percent of the lysophospholipase activity of the soluble fraction was recovered in the supernatant fraction and the recovery of the phospholipase B activity was $272 \%$.

2. Ammonium sulfate fractionation. The $\mathrm{pH}$ 4.0 supernatant was brought to $90 \%$ saturation with solid ammonium sulfate. After 30 min of stirring, the precipitate was removed by centrifugation at $10,000 \times g$ for $15 \mathrm{~min}$. The resulting supernatant was concentrated by ultrafiltration with an Immersible CX-30 (Millipore Co., Bedford, U.S.A.) and dialyzed against $25 \mathrm{~mm}$ Tris- $\mathrm{HCl}$ buffer ( $\mathrm{pH} 7.5)$ containing $0.5 \mathrm{~mm} \quad p$-chloromercuribenzoate. Lysophospholipase and phospholipase B activities were purified 78- and 871-fold from the soluble fraction with 61 and $685 \%$ recovery, respectively.

3. DEAE-Sepharose CL-6B column chromatography. The dialyzed fraction was put on a DEAE-Sepharose CL-6B column $(1.5 \times 15 \mathrm{~cm})$ equilibrated with $25 \mathrm{~mm}$ Tris- $\mathrm{HCl}$ buffer $(\mathrm{pH}$ 7.5). After elution with the same buffer, a linear gradient of 0 to $0.3 \mathrm{M} \mathrm{NaCl}$ dissolved in the same buffer was applied. The enzyme was eluted with the buffer containing $0.05 \sim 0.11 \mathrm{M}$ $\mathrm{NaCl}$. The fractions with enzyme activity were combined and concentrated by ultrafiltration.

4. Sepharose $4 B$ column chromatography. 
Table I. Purification of Phospholipase B from $S$. cerevisiae

\begin{tabular}{|c|c|c|c|c|c|c|}
\hline \multirow{2}{*}{ Fraction } & \multirow{2}{*}{$\begin{array}{l}\text { Protein } \\
(\mathrm{mg})\end{array}$} & \multicolumn{2}{|c|}{$\begin{array}{l}\text { Total activity } \\
\quad \text { (units) }\end{array}$} & \multicolumn{2}{|c|}{$\begin{array}{l}\text { Specific activity } \\
\quad \text { (units/mg) }\end{array}$} & \multirow{2}{*}{ LPLase/PLase B } \\
\hline & & LPLase $^{a}$ & PLase $\mathrm{B}^{b}$ & LPLase & PLase B & \\
\hline Soluble fraction & 11,163 & 9,598 & 53.3 & 0.86 & 0.0048 & 180 \\
\hline pH 4.0 supernatant & 5,523 & 7,534 & 145 & 1.36 & 0.026 & 52 \\
\hline$\left(\mathrm{NH}_{4}\right)_{2} \mathrm{SO}_{4}$ supernatant & 87.4 & 5,832 & 365 & 66.7 & 4.18 & 16 \\
\hline DEAE-Sepharose CL-6B & 28.3 & 5,095 & 318 & 180 & 11.2 & 16 \\
\hline Sepharose 4B & 13.6 & 2,888 & 181 & 212 & 13.3 & 16 \\
\hline Bio-Gel HTP & 1.59 & 422 & 27.2 & 265 & 17.1 & 16 \\
\hline
\end{tabular}

${ }^{a}$ LPLase, lysophospholipase.

b PLase B, phospholipase B.

The same abbreviations were used in the following tables.

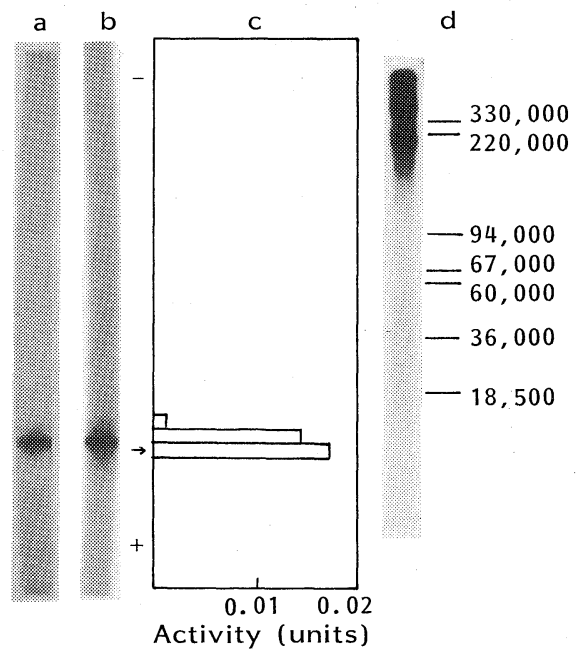

FIG. 1. Electrophoretic Patterns of the Purified Enzyme in the Agarose-acrylamide Gel System (a, b, c) and in the SDS System (d).

The experimental conditions are described in the text. a, protein staining with Amido Black 10B; b, carbohydrate staining with PAS; c, lysophospholipase activity; d, double-staining with PAS and Coomassie Brilliant Blue G-250. Standard proteins were thyroglobulin $(330,000)$, ferritin (half unit) $(220,000)$, phosphorylase $b(94,000)$, bovine serum albumin $(67,000)$, catalase $(60,000)$, lactate dehydrogenase $(36,000)$, ferritin (monomer) $(18,500) . \rightarrow$, Bromophenol Blue.

The concentrated solution was put on a Sepharose 4B column $(1.2 \times 72 \mathrm{~cm})$ equilibrated with $25 \mathrm{~mm}$ Tris- $\mathrm{HCl}$ buffer ( $\mathrm{pH} 7.5$ ). The column was eluted with the same buffer at a flow rate of $2.2 \mathrm{ml} / \mathrm{hr}$ and fractions of $1 \mathrm{ml}$ were collected. Fractions with enzyme activity were combined and dialyzed against $20 \mathrm{~mm}$ phosphate buffer, $\mathrm{pH}$ 7.5.

5. Bio-Gel HTP column chromatography. The dialyzed sample was put on a Bio-Gel HTP column $(1 \times 12 \mathrm{~cm})$ equilibrated with $20 \mathrm{~mm}$ phosphate buffer ( $\mathrm{pH}$ 7.5). The column was washed first with the same buffer and then eluted stepwise with 50, 200, and $400 \mathrm{~mm}$ phosphate buffer ( $\mathrm{pH}$ 7.5). The enzyme activity was eluted with 200 and $400 \mathrm{~mm}$ phosphate buffer, called Fractions I and II. Both fractions were dialyzed against Tris- $\mathrm{HCl}$ buffer $(25 \mathrm{~mm}, \mathrm{pH}$ 7.5 ). Fraction I contained $4.4 \%$ of the original lysophospholipase activity with a 308 -fold increase of specific activity while Fraction II contained $3.6 \%$ of the original lysophospholipase activity with a 103-fold increase of specific activity. Fraction I was used as the purified enzyme preparation; it migrated as a single glycoprotein band in agarose-polyacrylamíde gel electrophoresis (Fig. 1a, b, c). The purification procedure is summarized in Table I.

\section{Molecular weight}

Figure 2 shows a typical elution profile of the enzyme. The enzyme activity ranged from about 280,000 (I) to 420,000 (II). The enzyme gave also broad bands (around 210,000 and over 330,000) on SDS-polyacrylamide gel electrophoresis in the absence of 2-mercaptoethanol (Fig. 1d). These bands were poorly stained with Coomassie Brilliant Blue, but 


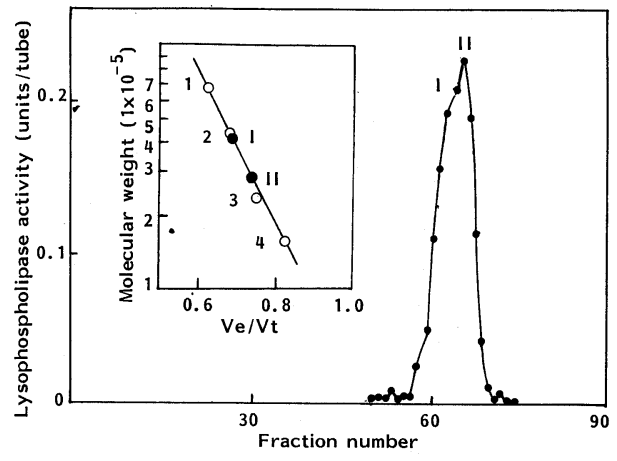

FIG. 2. Determination of the Molecular Weight of the Purified Enzyme by Gel Filtration on a Sepharose 4B Column.

1 , thyroglobulin $(669,000) ; 2$, ferritin $(440,000) ; 3$, catalase $(232,000) ; 4$, aldolase $(158,000)$.

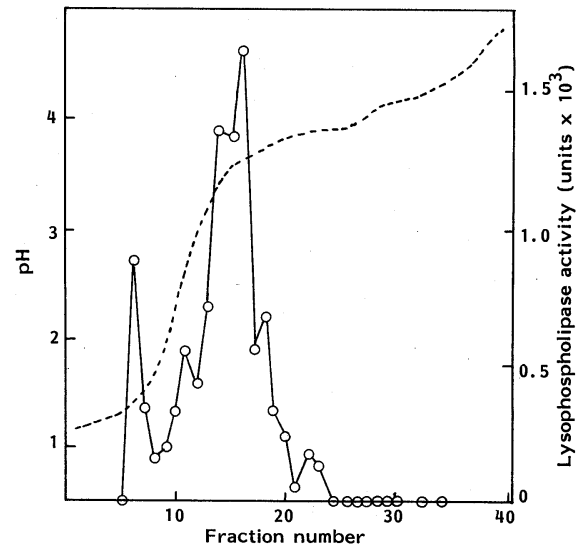

FIG. 3. Isoelectric Focusing of the Purified Enzyme.

The experimental conditions are described in the text ,$---- \mathrm{pH} ; \mathrm{O}$, lysophospholipase activity.

after stained well with the PAS reagent.

\section{Isoelectric point}

On isoelectric focusing of the purified enzyme, the major peak of lysophospholipase activity was seen at pH 3.6 (Fig. 3).

\section{Effects of $p H$}

The maximal phospholipase B activity was observed at about pH $3.5 \sim 4.0$, and lysophospholipase activity had the same $\mathrm{pH}$ optimum (Fig. 4).

\section{Effects of detergents}

Phospholipase B activity of the purified

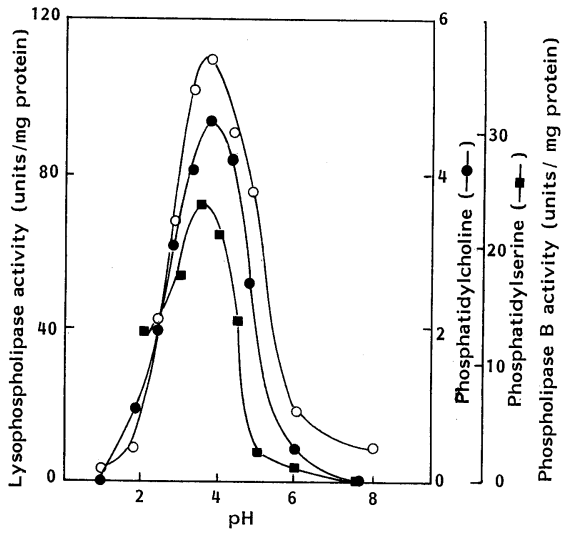

Fig. 4. pH-Activity Curves of the Purified Enzyme.

Substrates: $\bigcirc$, lysophosphatidylcholine; $\bullet$, phosphatidylcholine; $\mathbf{\square}$, phosphatidylserine. As buffers, acetate buffer for $\mathrm{pH} 1 \sim 5$, phosphate buffer for $\mathrm{pH} 6$, and Tris- $\mathrm{HCl}$ buffer for $\mathrm{pH} 7.5 \sim 8$ were used.

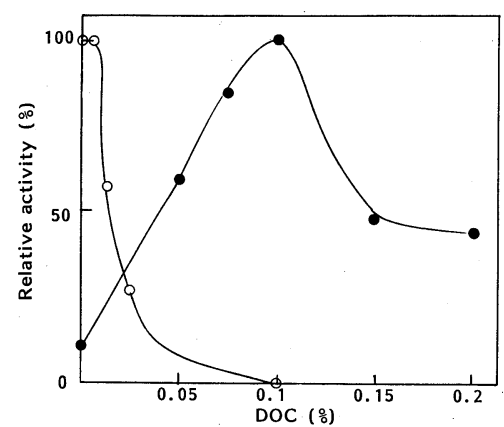

FIG. 5. Effects of DOC on Phospholipase B and Lysophospholipase Activities of the Purified Enzyme.

Both activities were measured by the standard assay method described in the text except that various concentrations of DOC were used. - phospholipase B activity; $\bigcirc$, lysophospholipase activity.

enzyme was extensively stimulated by $0.1 \%$ DOC, but lysophospholipase activity was completely inhibited by the detergent (Fig. 5). SDS and Triton X-100 inhibited both activities (Table II).

\section{Effects of metal ions}

$\mathrm{Ca}^{2+}, \mathrm{Hg}^{2+}$, and EDTA hardly affected either of the activities of the enzyme (Table III). $\mathrm{Fe}^{2+}$ and $\mathrm{Fe}^{3+}$ almost completely inhibited phospholipase $\mathrm{B}$ activity. $\mathrm{Fe}^{3+}$ also inhibited lysophospholipase activity, but $\mathrm{Fe}^{2+}$ did not. 
Table II. Effects of Detergents on PhosphoLIPASE B AND LYSOPHOSPHOLIPASE ACTIVITIES of the Purified EnZyMe

Phospholipase B activity was measured by the standard assay except that one of the indicated detergents replaced DOC.

\begin{tabular}{|c|c|c|c|}
\hline \multirow{2}{*}{ Detergent } & \multirow{2}{*}{$\begin{array}{c}\text { Concentration } \\
(\%)\end{array}$} & \multicolumn{2}{|c|}{ Relative activity $(\%$} \\
\hline & & PLase B & LPLase \\
\hline None & & 12 & 100 \\
\hline DOC & 0.1 & 100 & 0 \\
\hline \multirow[t]{2}{*}{ SDS } & 0.1 & 0 & 4 \\
\hline & 0.025 & 1 & 8 \\
\hline \multirow[t]{2}{*}{ Triton X-100 } & 0.1 & 1 & 37 \\
\hline & 0.025 & 0 & 57 \\
\hline
\end{tabular}

Table III. Effects of Metal Ions on PhosphoLIPASE B AND LySOPHOSPHOLIPASE ACTIVITIES of THE Purified EnZyMe

$\mathrm{Fe}^{2+}$ was used in the sulfate form and the other metal ions were used in the chloride form.

\begin{tabular}{|c|c|c|c|}
\hline \multirow{2}{*}{ Addition } & \multirow{2}{*}{$\begin{array}{l}\text { Concentration } \\
(\mathrm{mm})\end{array}$} & \multicolumn{2}{|c|}{ Relative activity $(\%)$} \\
\hline & & PLase B & LPLase \\
\hline None & & 100 & 100 \\
\hline $\mathrm{Ca}^{2+}$ & 5 & 95 & 100 \\
\hline $\mathrm{Fe}^{2+}$ & 5 & 6 & 100 \\
\hline $\mathrm{Fe}^{3+}$ & 5 & 1 & 43 \\
\hline $\mathrm{Hg}^{2+}$ & 5 & 100 & 96 \\
\hline EDTA & 5 & 102 & 101 \\
\hline
\end{tabular}

\section{Effect of substrate concentration}

The effect of substrate concentration on phospholipase B activity of the purified enzyme was examined. Under the standard assay conditions, no Michaelis-Menten saturation curve was obtained on phospholipase B activity and the activity was inhibited by high substrate conditions (Fig. 6A). However, when the concentration of $\mathrm{DOC}$ in the reaction mixture was varied in proportion to that of phosphatidylcholine, the molar ratio of DOC to the substrate being $2.4: 1$, a saturation curve was obtained (Fig. 6B). The $\mathrm{Km}$ was $0.63 \mathrm{~mm}$ and the maximal velocity of the phospholipase $\mathrm{B}$ activity was $10 \mathrm{units} / \mathrm{mg}$ protein. The $\mathrm{Km}$ was $0.05 \mathrm{~mm}$ and the maximal velocity of lysophospholipase activity of the purified enzyme

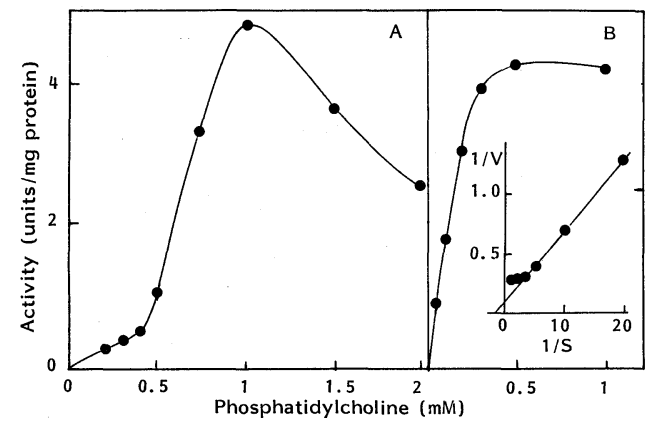

FIG. 6. Effect of Substrate Concentration on Phospholipase B Activity of the Purified Enzyme.

A, the activity was measured by the standard assay except that various concentrations of phosphatidylcholine were used; B, the activity was measured as A except that the concentration of DOC was varied in proportion to that of the substrate as described in the text.

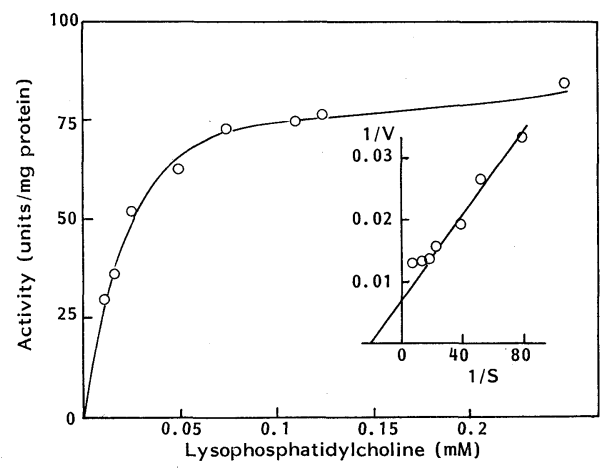

FIG. 7. Effect of Substrate Concentration on Lysophospholipase Activity of the Purified Enzyme.

was 154 units/mg protein (Fig. 7).

\section{Positional specificity}

In the presence of $0.1 \%$ DOC, with which hydrolysis of lysophosphatidylcholine was almost completely inhibited as described above, the purified enzyme hydrolyzed $1-\left[1-{ }^{14} \mathrm{C}\right]$ palmitoyl-2-acyl-sn-glycero-3-phosphocholine, accumulating radioactive lysophosphatidylcholine and fatty acids (Fig. 8A). On the other hand, during hydrolysis of 1palmitoyl-2-[ $\left.{ }^{14} \mathrm{C}\right]$ oleoyl-sn-glycero-3-phosphocholine, no actual accumulation of lysophosphatidylcholine was observed (Fig. 8B). These results suggest that the purified enzyme was phospholipase $\mathrm{B}$ which attacked 

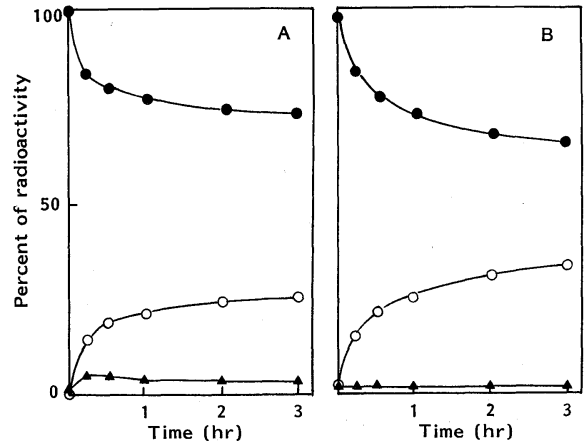

FIG. 8. Hydrolysis of Phosphatidylcholine by the Purified Enzyme.

Substrate: A, 1-[1- $\left.{ }^{14} \mathrm{C}\right]$ palmitoyl-2-acyl-sn-glycero-3-phos phocholine; B, 1-palmitoyl-2-[ $\left.{ }^{14} \mathrm{C}\right]$ oleoyl-sn-glycero-3phosphocholine. 0 , phosphatidylcholine; $\boldsymbol{\Delta}$, lysophosphatidylcholine; $\bigcirc$, fatty acids.

Table IV. Hydrolysis of Various PhosphoGLYCERIDES BY THE PURIFIED ENZYME

\begin{tabular}{|c|c|c|}
\hline Substrate & $\begin{array}{l}\text { Concentration } \\
(\mathrm{mm})\end{array}$ & $\begin{array}{c}\text { Activity } \\
\text { (units/mg) }\end{array}$ \\
\hline Phosphatidylcholine & 1.0 & 1.4 \\
\hline Phosphatidylethanolamine & 1.0 & 1.0 \\
\hline Phosphatidylinositol & 1.0 & 1.9 \\
\hline Phosphatidylserine & 1.0 & 4.6 \\
\hline 1-Acyl-GPC ${ }^{a}$ & 0.25 & 18.6 \\
\hline 2-Acyl-GPC ${ }^{b}$ & 0.21 & 2.8 \\
\hline
\end{tabular}

a 1-Acyl-GPC, 1-acyl-sn-glycero-3-phosphocholine.

b 2-Acyl-GPC, 2-acyl-sn-glycero-3-phosphocholine.

the acyl ester bonds of phosphatidylcholine sequentially, first the 2-acyl and then the 1-acyl groups. Table IV shows the relative rates of hydrolysis of various phosphoglycerides. Phosphatidylserine was hydrolyzed most rapidly among the diacylphosphoglycerides tested. As shown in Fig. 4, the optimum $\mathrm{pH}$ of phosphatidylserine hydrolysis was almost the same as that of phosphatidylcholine. 1-Acyl$s n$-glycero-3-phosphocholine was hydrolyzed approximately 7 times faster than 2-acyl$s n$-glycero-3-phosphocholine.

\section{DISCUSSION}

As shown in Table I, the soluble fraction obtained from a yeast cell homogenate contained lysophospholipase activity and phos- pholipase B activity in a ratio of $180: 1$. However, the phospholipase $\mathrm{B}$ activity was greatly activated by acid treatment and ammonium sulfate fractionation. Kusano et al. ${ }^{16)}$ reported that phospholipase A from Pseudomonas aeruginosa was activated by salting-out treatment with ammonium sulfate and the involvement of a protease in this activation was suggested. However, in the case of this enzyme, preincubation of the soluble fraction at $20^{\circ} \mathrm{C}$ for $3 \mathrm{hr}$ caused neither activation nor inactivation of the enzyme, and the addition of the precipitate fraction from ammonium sulfate fractionation into phospholipase B assay mixture containing the ammonium sulfate supernatant fraction as an enzyme source caused strong inhibition of the phospholipase B activity (data not given). Therefore, the observed activation of a soluble phospholipase B of baker's yeast during purification may be due to the removal of an endogenous regulating factor. The ratio of lysophospholipase activity to phospholipase $B$ activity of the ammonium sulfate supernatant fraction was $16: 1$, and almost the same values were obtained in three different purification experiments. The ratio was almost constant throughout the further purification, which suggested that the two activities were due to the same enzyme protein.

This enzyme was a phosholipase B according to the definition of McMurray and Magee. ${ }^{17)}$ Enzymatic characteristics of this enzyme were almost the same as those of the membrane-bound phospholipase $\mathbf{B}$ purified previously $^{4)}$ in $\mathrm{pH}$ optimum, isoelectric point, detergent-dependency in its phospholipase B activity, positional specificity, and effects of some ions other than $\mathrm{Fe}^{2+}$. However, this enzyme was soluble whereas the membranebound phospholipase B was so tightly bound to the membranes that it could not be released by washing with an alkaline buffer containing EDTA and it could be solubilized by DOC with other membrane proteins. The apparent $\mathrm{Km}$ of the phospholipase B activity of the former was about three times that of the latter, whereas the maximal velocity was almost the 
same. The ratio of lysophospholipase to phospholipase B activity of the former was also about three times greater than that of the latter. The relations between the soluble and membrane-bound phospholipase B in S. cerevisiae are now under investigation. This enzyme resembled purified phospholipase B of Penicillium notatum with respect to $\mathrm{pH}$ optimum, acidic isoelectric point, and positional specificity but differed in molecular weight and sensitivity to some detergents. ${ }^{18)}$ Phospholipase B activity of this enzyme was extremely inhibited by Triton X-100. However, this detergent stimulated various phospholipases such as phospholipase B purified from $P$. notatum $^{18)}$ and Streptomyces hiroshimensis, ${ }^{19)}$ phospholipase $\mathrm{A}_{1}$ purified from Mycobacterium phlei $^{20)}$ and Corticium centrifugum, ${ }^{21)}$ and phospholipase $\mathrm{A}_{2}$ from brain microsomes, ${ }^{22)}$ but slightly inhibited phospholipase B from C. centrifugum. ${ }^{23)}$

\section{REFERENCES}

1) R. Kokke, G. J. M. Hooghwinkel, H. L. Booij, H. Van den Bosch, L. Zelles, E. Mulder and L. L. M. Van Deenen, Biochim. Biophys. Acta, 70, 351 (1963).

2) H. Van den Bosch, H. A. Bonte and L. L. M. Van Deenen, Biochim. Biophys. Acta, 98, 648 (1965).

3) H. Van den Bosch, H. M. Van der Elzen and L. L. M. Van Deenen, Lipids, 2, 279 (1967).

4) M. Ichimasa, T. Morooka and T. Niimura, $J$. Biochem., 95, 137 (1984).
5) B. Åkesson, J. Elovoson and G. Arvidson, Biochim. Biophys. Acta, 218, 44 (1970).

6) H. Eibl and W. E. M. Lands, Biochemistry, 9, 423 (1970).

7) T. Okumura, J. Sugatani and K. Saito, Arch. Biochem. Biophys., 211, 419 (1981).

8) G. R. Bartlett, J. Biol. Chem., 234, 466 (1959).

9) E. G. Bligh and W. J. Dyer, Can. J. Biochem. Physiol., 37, 911 (1959).

10) P. Andrews, Biochem. J., 96, 595 (1965).

11) K. Nakamura and E. Masuyama; Seikagaku, 52, 497 (1980).

12) R. M. Zacharius, T. E. Zell, J. H. Morrison and J. J. Woodlock, Anal. Biochem., 30, 148 (1975).

13) K. Weber and M. Osborn, J. Biol. Chem., 244, 4406 (1969).

14) J. N. Behnke, S. M. Dagher, T. H. Massey and W. C. Jr. Deal, Anal. Biochem., 69, 1 (1975).

15) O. H. Lowry, N. J. Rosebrough, A. L. Farr and R. J. Randall, J. Biol. Chem., 193, 265 (1951).

16) T. Kusano, K. Izaki and H. Takahashi, Agric. Biol. Chem., 44, 1779 (1980).

17) W. C. McMurray and W. L. Magee, Ann. Rev. Biochem., 41, 129 (1972).

18) N. Kawasaki, J. Sugatani and K. Saito, J. Biochem., 77, 1233 (1975).

19) Y. Okawa and T. Yamaguchi, Agric. Biol. Chem., 40, 277 (1976).

20) M. Nishijima, Y. Akamatsu and S. Nojima, J. Biol. Chem., 249, 5658 (1974).

21) S. Uehara, K. Hasegawa and K. Iwai, Agric. Biol. Chem., 43, 517 (1979).

22) N. N. C. Gray and K. P. Strickland, Can. J. Biochem., 60, 108 (1982).

23) S. Uehara, K. Hasegawa and K. Iwai, Bull. Res. Inst. Food, Sci., Kyoto Univ., 42, 9 (1979). 